\title{
PENGARUH MODEL PEMBELAJARAN KOOPERATIF TIPE STAD DENGAN MEDIA GEOGEBRA TERHADAP MOTIVASI DAN PRESTASI BELAJAR MATEMATIKA PADA SISWA KELAS VIII SMP NEGERI 1 ABANG
}

\author{
I Made Mawa, I Made Candiasa, Ketut Agustini \\ Program Studi Teknologi Pembelajaran, Program Pascasarjana \\ Universitas pendidikan Ganesha \\ Singaraja, Indonesia \\ e-mail : \{made.mawa, made.candiasa, ketut.agustini\}@pasca.undiksha.ac.id
}

\begin{abstract}
Abstrak
Penelitian ini bertujuan untuk mengetahui pengaruh model pembelajaran kooperatif tipe STAD dengan media Geogebra terhadap motivasi dan prestasi belajar matematika siswa. Penelitian ini termasuk quasi eksperimen dengan rancangan non equivalent pretest-posttest control group design. Populasi penelitian siswa kelas VIII SMP Negeri 1 Abang sebanyak 340 orang. Sampel penelitian adalah kelas VIII B, VIII D dan VIII H sebanyak 102 orang, yang diambil secara random. Data yang dikumpulkan adalah motivasi dan prestasi belajar matematika siswa. Data dianalisis dengan teknik MANCOVA pada taraf signifikansi $5 \%$. Hasil penelitian menunjukkan: (1) terdapat perbedaan motivasi dan prestasi belajar matematika antara siswa yang belajar dengan model pembelajaran kooperatif tipe STAD dengan media GeoGebra, model pembelajaran kooperatif tipe STAD, dan model pembelajaran konvensional, (2) terdapat perbedaan motivasi belajar matematika antara siswa yang belajar dengan model pembelajaran kooperatif tipe STAD dengan media GeoGebra, model pembelajaran kooperatif tipe STAD, dan model pembelajaran konvensional, dan (3) terdapat perbedaan prestasi belajar matematika antara siswa yang belajar dengan model pembelajaran kooperatif tipe STAD dengan media GeoGebra, model pembelajaran kooperatif tipe STAD, dan model pembelajaran konvensional. Berdasarkan temuan penelitian ini dapat disimpulkan bahwa pembelajaran kooperatif tipe STAD dengan media Geogebra berpengaruh secara signifikan terhadap motivasi dan prestasi belajar matematika siswa.
\end{abstract}

Kata Kunci: STAD, Media Geogebra, Motivasi, Prestasi Belajar Matematika

\begin{abstract}
This study aimed to finding out the effect of STAD cooperative learning with Geogebra to motivation and achievement mathematics learning. This research employed non equivalence pretest-posttest control group design. The population of this study were 340 students of eighth grade at SMP Negeri 1 Abang. The sample were 102 students of the class VIII B, VIII D and VIII H that selected by random sampling technique. The data was collected through motivation questionare and mathematics achievement test. The data were analyzed using multivariat analysis of covarians. The result of this study showed that (1) there was a significant different on motivation and achievement mathematics learning to students who learned with STAD cooperative learning with Geogebra, STAD cooperative learning, and conventional learning; (2) there was a significant different on motivation mathematics learning to students who learned with STAD cooperative learning with Geogebra, STAD cooperative learning, and conventional learning; (3) there was a significant different on achievement mathematics learning to students who learned with STAD cooperative learning with Geogebra, STAD cooperative learning, and conventional learning. Based on the research finding, it can be concluded that STAD cooperative learning with Geogebra has effect to motivation and acheivement mathematics learning.
\end{abstract}

Key words : STAD, Geogebra, Motivation, Mathematics Learning Achievement 


\section{PENDAHULUAN}

Matematika merupakan mata pelajaran yang dipelajari oleh semua siswa pada setiap jenjang sekolah, dari sekolah dasar, sekolah menengah bahkan sampai ke pendidikan tinggi. Matematika diharapkan mampu menjadi salah satu sarana untuk meningkatkan daya nalar siswa dan dapat meningkatkan kemampuan dalam mengaplikasikan matematika menghadapi tantangan hidup sehingga mampu memecahkan masalah nyata dalam kehidupan sehari-hari.

Cornelus (dalam Kawiwati, 2009) mengatakan bahwa ada banyak alasan tentang perlunya siswa mempelajari matematika, antara lain: (1) merupakan sarana berpikir yang jelas dan logis, (2) sarana memecahkan masalah dalam kehidupan sehari-hari, (3) sarana mengenal pola hubungan dan generalisasi pengalaman, (4) sarana untuk mengembangkan kreativitas, dan (5) sarana untuk meningkatkan kesadaran terhadap perkembangan budaya.

Demikian banyak manfaat yang diperoleh dari pembelajaran matematika, seharusnya matematika merupakan salah satu pelajaran yang digemari oleh siswa. Tetapi pada kenyataannya prestasi belajar yang diperoleh siswa dalam pelajaran matematika hingga kini masih belum sesuai dengan apa yang diharapkan. Secara umum, siswa beranggapan bahwa matematika merupakan pelajaran yang sulit, tidak menarik dan membosankan, penuh misteri, bahkan dianggap tidak ada kaitannya dengan kehidupan sehari-hari. Banyak juga orang yang tidak mengetahui manfaat matematika dan banyak pula orang yang berpendapat bahwa matematika itu tidak menarik. Hal ini dipertegas oleh Suherman (1993) yang menyatakan bahwa banyak orang yang telah mengetahui dan mengakui manfaat dan bantuan matematika kepada bidang studi lain dan kehidupan, namun tidak sedikit pula yang memandang bahwa matematika itu tidak menarik dan tidak berguna.
Dari pengamatan peneliti di SMP Negeri 1 Abang menunjukkan bahwa masih banyak siswa yang tidak menyenangi pelajaran matematika bahkan ada juga siswa yang takut pada matematika. Sikap siswa yang tidak menyenangi mata pelajaran matematika tentunya akan menyebabkan prestasi belajar matematika siswa masih rendah. Sebagai indikator rendahnya prestasi belajar matematika siswa di SMP Negeri 1 Abang adalah nilai rata-rata hasil Ujian Nasional tahun pelajaran 2014/2015 untuk mata pelajaran matematika yang hanya mencapai 3,24 dan masih berada pada kategori $\mathrm{E}$.

Banyak faktor yang mempengaruhi prestasi belajar matematika, baik faktor dari dalam diri siswa (internal) maupun faktor dari luar diri siswa (eksternal). Faktor internal meliputi minat, bakat dan motivasi siswa sedangkan faktor eksternal antara lain kondisi lingkungan sekolah, sarana prasarana, model pembelajaran yang diterapkan, dan media yang digunakan dalam proses pembelajaran. Model pembelajaran yang selama ini diterapkan oleh guru diidentifikasi merupakan salah satu faktor yang berpengaruh terhadap rendahnya prestasi belajar matematika siswa di SMP Negeri 1 Abang. Dalam proses pembelajaran selama ini, guru menjelaskan materi pelajaran di depan kelas dan menulis di papan tulis, memberikan contoh soal, kemudian siswa diberikan soal untuk dikerjakan. Hal ini menyebabkan siswa kurang berpartisipasi aktif dalam pembelajaran, siswa yang aktif hanya siswa yang memiliki kemampuan lebih. Ini menunjukkan bahwa guru masih menerapkan pembelajaran konvensional yang berpusat pada guru (teacher centered) dan belum menggunakan pembelajaran inovatif yang berpusat pada siswa (student centered) seperti yang diharapkan pada kurikulum 2006 maupun Kurikulum 2013. Paparan situasi di atas mengindikasikan perlunya penerapan model pembelajaran inovatif yang mampu melibatkan seluruh siswa dalam proses pembelajaran dan juga mampu 
membangkitkan motivasi siswa dalam belajar matematika.

Trianto (2012) menyatakan bahwa memasuki abad ke-21 terdapat tujuh pergeseran paradigma dalam proses pembelajaran yaitu: 1) dari pola belajar secara terminal bergeser ke pola belajar sepanjang hayat (long life education); 2) dari pola belajar terfokus pada penguasaan pengetahuan saja menjadi terfokus pada sistem belajar secara holistik; 3) dari hubungan antara guru dan pebelajar yang konfrontatif menjadi sebuah hubungan yang bersifat kemitraan; 4) dari penekanan skolastik bergeser menjadi penekanan berfokus pada nilai; 5) dari hanya buta aksara, bertambah dengan adanya buta teknologi, budaya dan komputer; 6) dari sistem kerja terisolasi (sendiri-sendiri) bergeser menjadi sistem kerja melalui tim (team work), dan 7) dari konsentrasi eksklusif kompetitif menjadi sistem kerja sama. Pergeseran paradigma ini, khususnya dua paradigma yang terakhir menunjukkan bahwa dalam pembelajaran saat ini sangat penting memilih model pembelajaran yang mampu menumbuhkan kerja sama antar siswa baik kerja sama dalam kelompok maupun kerjasama antar seluruh siswa dalam kelas. Model pembelajaran inovatif yang relevan dengan pergeseran paradigma ini dan dapat dijadikan sebagai alternatif dalam pembelajaran adalah model pembelajaran kooperatif (cooperative learning).

Pertimbangan lain pentingnya penerapan model pembelajaran kooperatif adalah bahwa pada pembelajaran kompetitif dan individualistis yang masih terjadi dalam dunia pendidikan di Indonesia saat ini, mempunyai beberapa kelemahan. Kelemahan-kelemahan pada pembelajaran kompetitif dan individualistis antara lain: 1) kadang terjadi kompetisi siswa yang tidak sehat, misalnya jika seorang siswa diberikan pertanyaan oleh guru, siswa yang lain berharap jawaban yang diberikan salah; 2) siswa yang berkemampuan rendah akan kurang termotivasi; 3) siswa yang berkemampuan rendah akan sulit untuk sukses dan akan semakin tertinggal; dan 4) dapat membuat siswa lainnya frustasi. Untuk menghindari hal-hal tersebut dan agar siswa dapat membantu siswa yang lain untuk mencapai sukses, maka jalan keluarnya adalah denga belajar secara kooperatif (Trianto, 2012).

Salah satu model pembelajaran kooperatif yang paling tepat untuk masalah di atas adalah model pembelajaran kooperatif tipe Student Teams Achievement Division (STAD). Model pembelajaran kooperatif tipe STAD merupakan salah satu pembelajaran kooperatif yang diterapkan untuk menghadapi kemampuan siswa yang heterogen. Model ini dipandang sebagai metode yang paling sederhana, dibandingkan model pembelajaran kooperatif yang lain (Trianto, 2012), sehingga model pembelajaran kooperatif tipe STAD sangat cocok bagi guru yang baru memulai menerapkan model pembelajaran kooperatif. Model kooperatif tipe STAD juga lebih sesuai untuk semua jenjang kelas, berbagai materi ajar, dibandingkan dengan tipe-tipe model belajar kooperatif yang lain

Selain itu, dari hasil wawancara dan pengamatan peneliti juga didapatkan bahwa selama ini guru sangat jarang menggunakan media pembelajaran yang mampu memvisualisasikan konsep-konsep matematika yang abstrak. Guru memang sudah menggunakan media pembelajaran, tetapi media pembelajaran yang digunakan jarang melibatkan peran aktif siswa dalam pembelajaran. Padahal apabila media pembelajaran tersebut dapat melibatkan siswa secara aktif maka akan dapat meningkatkan motivasi belajar siswa sehingga berimplikasi pada peningkatan prestasi belajarnya. Sesuai dengan apa yang diungkapkan oleh Suherman (2003), di mana penggunaan media pembelajaran akan dapat meningkatkan motivasi belajar siswa. Hal sama juga diungkapkan Djamarah dan Zain (2006) yang menyatakan fungsi media pembelajaran adalah sebagai alat bantu dalam pembelajaran, sehingga 
dapat menciptakan suasana belajar yang kondusif.

Salah satu media pembelajaran yang dapat mengurangi kesulitan belajar karena materi yang sangat abstrak adalah dengan menggunakan media berbasis Teknologi Informasi dan Komunikasi (TIK) yaitu komputer. Hal ini sesuai dengan pendapat Widyaningrum (2012) yang menyatakan bahwa proses pembelajaran yang menggunakan komputer disebut pembelajaran berbasis ICT (Information and Communication Technology), dan dengan pembelajaran berbasis komputer siswa akan lebih mudah memahami konsep-konsep yang bersifat abstrak, hal ini pada akhirnya dapat meningkatkan hasil belajar. Pendapat lain menyatakan bahwa media dengan menggunakan TIK dapat membantu memvisualisasikan konsep abstrak dan mampu melibatkan peran aktif siswa dalam belajar. Menurut Suhariyanto (dalam Wulandari, 2011), pemanfaatan TIK dalam pembelajaran dapat memberikan dampak positif berupa (1) meningkatkan dan mengembangkan lingkungan belajar yang lebih efektif dan (2) membantu mengembangkan berpikir kritis dan kerjasama antar siswa dalam kelas. Lebih lanjut Hamalik (2008), menyatakan bahwa kegiatan pembelajaran berbantuan komputer dapat dilaksanakan untuk membantu siswa memahami konsep dan prinsip-prinsip yang berhubungan dengan matematika.

Pemanfaatan komputer dalam pembelajaran matematika semakin relevan mengingat karakteristik matematika yang memiliki objek-objek kajian bersifat abstrak. Objek matematika yang abstrak ini sering menjadi penyebab kesulitan siswa dalam belajar matematika. Di satu sisi objek matematika bersifat abstrak, sementara di sisi lain siswa belum mampu berpikir abstrak. Menurut Mahmudi (2010) media pembelajaran mempunyai peran yang penting guna menjembatani kesenjangan itu. Materi di SMP yang dapat disajikan dengan berbantuan komputer adalah materi geometri. Sebagaimana objek-objek matematika lainnya, objek geometri juga bersifat abstrak. Hal demikian berpotensi akan memunculkan berbagai kesulitan dalam mempelajarinya, terutama bagi siswa di kelas tingkat rendah, mengingat mereka pada umumnya belum mampu berpikir secara abstrak (Mahmudi, 2010).

Salah satu program komputer (software) yang dapat dimanfaatkan sebagai media pembelajaran matematika, khususnya geometri adalah GeoGebra. GeoGebra dikembangkan oleh Markus Hohenwarter pada Tahun 2001. Menurut Hohenwarter (2008), GeoGebra adalah program komputer (software) untuk membelajarkan matematika, khususnya geometri dan aljabar. Software GeoGebra dapat digunakan untuk membuat mathematical applet (mathlet). Yang dimaksud dengan mathlet adalah program komputer yang tidak terlalu besar yang fungsinya sebagai media untuk melakukan eksplorasi terhadap konsep-konsep matematika yang dipelajari (Suweken, 2011). Program ini dapat dimanfaatkan untuk meningkatkan pemahaman siswa terhadap konsep yang telah dipelajari maupun sebagai sarana untuk mengenalkan atau mengkonstruksi konsep baru. Berdasarkan hasil penelitian Suweken (2011), diperoleh bahwa penggunaan mathlet dalam pembelajaran matematika juga berpengaruh positif terhadap prestasi belajar siswa. GeoGebra merupakan software matematika dinamik (dynamic mathematics) yang dirancang untuk pembelajaran matematika di sekolah menengah ataupun perguruan tinggi (Preiner, 2008). GeoGebra bersifat multirepresentasi, yaitu (i) adanya tampilan aljabar, (ii) adanya tampilan grafis, dan (iii) adanya tampilan numerik. Ketiga tampilan ini saling terhubungkan secara dinamik (Suweken, 2011). Jika kita mengubah posisi sebuah titik pada tampilan grafis, maka perubahan tersebut akan tercermin pula pada tampilan numerik dan tampilan aljabar. Keunggulan inilah yang dapat membantu siswa dalam mempelajari objek-objek geometri yang bersifat abstrak. Karena keunggulan ini, media pembelajaran GeoGebra diharapkan mampu mengurangi kesulitan belajar siswa 
pada pembelajaran geometri dan mampu meningkatkan keterlibatan siswa dalam proses pembelajaran. Eka Aryasuta (2014) dalam hasil penelitiannya menyimpulkan bahwa prestasi belajar matematika siswa yang mengikuti pembelajaran model PBM dengan media berbantuan geogebra lebih baik daripada prestasi belajar matematika siswa yang mengikuti pembelajaran model PBM, baik pada siswa yang mempunyai tingkat ketangguhan tinggi maupun pada siswa yang mempunyai tingkat ketangguhan rendah. Terkait dengan motivasi belajar dan penerapan media GeoGebra dalam pembelajaran, Wulan Fitriyani \& Sugiman (2014), dalam penelitian "pengembangan perangkat pembelajaran teorema pythagoras dengan pendekatan IDEAL berbantuan GeoGebra" menyimpulkan bahwa produk perangkat pembelajaran yang dikembangkan telah memenuhi kriteria sangat efektif ditinjau dari prestasi dan motivasi belajar siswa, sebanyak $83,33 \%$ siswa berhasil mencapai KKM yang ditetapkan dan $87,5 \%$ siswa memiliki motivasi belajar matematika yang tinggi.

Berdasarkan uraian di atas, dalam penelitian ini akan diungkapkan secara empiris pengaruh model pembelajaran kooperatif tipe Student Teams Achievement Division (STAD) dengan media Geogebra terhadap motivasi dan prestasi belajar matematika pada siswa kelas VIII SMP Negeri 1 Abang.

Tujuan penelitian ini adalah: 1) untuk mendeskripsikan perbedaan motivasi dan prestasi belajar matematika antara siswa yang belajar dengan model pembelajaran kooperatif tipe STAD dengan media GeoGebra, model pembelajaran kooperatif tipe STAD, dan model pembelajaran konvensional; 2) untuk mendeskripsikan perbedaan motivasi belajar matematika antara siswa yang belajar dengan model pembelajaran kooperatif tipe STAD dengan media GeoGebra, model pembelajaran kooperatif tipe STAD, dan model pembelajaran konvensional; dan 3) untuk mendeskripsikan perbedaan prestasi belajar matematika antara siswa yang belajar dengan model pembelajaran kooperatif tipe STAD dengan media GeoGebra, model pembelajaran kooperatif tipe STAD, dan model pembelajaran konvensional

\section{METODE}

Tujuan penelitian ini adalah untuk mengetahui pengaruh model pembelajaran kooperatif tipe STAD dengan media Geogebra terhadap motivasi dan prestasi belajar matematika siswa. Penelitian ini merupakan penelitian eksperimen semu (quasi experimental) dengan dengan rancanagn non equivalent pretest-post test control group design. Populasi penelitian adalah seluruh siswa kelas VIII SMP Negeri 1 Abang tahun pelajaran 2016/2017 sebanyak 340 orang yang terbagi menjadi 10 kelas. Pengambilan sampell dilakukan dengan teknik random sampling dan kelas VIII B, kelas VIII D dan kelas VIII H terpilih sebagai sampel penelitian. Banyak sampel secara keseluruhan adalah 102 orang siswa.

Variabel penelitian yang terlibat terdiri atas variabel bebas dan variabel terikat. Variabel bebas dalam penelitian inii adalah model pembelajaran, yaitu modei pembelajaran kooperatif tipe STAD dengan media Geogebra, model pembelajaran kooperatif tipe STAD, dan model pembelajaran konvensional. Variabel terikat adalah motivasi belajar dan prestasi belajar matematika. Data tentang motivasi belajar matematika dikumpulkan dengan kuisioner motivasi belajar, sedangkan data prestasi belajar matematika dikumpulkan dengan tes prestasi belajar. Sebelum digunakan dalam pengumpulan data, instrumen-instrumen yang disusun, terlebih dahulu dilakukan tes uji coba. Hasil uji coba instrumen dianalisis untuk mengetahui validitas butir tes, indeks daya beda butir, indeks kesukaran butir, efektivitas pengecoh, dan reliabilitas tes.

Hipotesis yang dirumuskan adalah: (1) terdapat perbedaan motivasi dan prestasi belajar matematika antara siswa yang belajar dengan model pembelajaran kooperatif tipe STAD dengan media GeoGebra, model pembelajaran kooperatif tipe STAD, dan model pembelajaran 
konvensional, (2) terdapat perbedaan motivasi belajar matematika antara siswa yang belajar dengan model pembelajaran kooperatif tipe STAD dengan media GeoGebra, model pembelajaran kooperatif tipe STAD, dan model pembelajaran konvensional, dan (3) terdapat perbedaan prestasi belajar matematika antara siswa yang belajar dengan model pembelajaran kooperatif tipe STAD dengan media GeoGebra, model pembelajaran kooperatif tipe STAD, dan model pembelajaran konvensional.

Sebelum uji hipotesis, terlebih dahulu dilakukan uji asumsi yang meliputi uji normalitas data, uji homogenitas, uji linearitas, uji homogenitas matriks varians/ covarians dan uji kolinearitas antar variabel terikat. Uji normalitas data bertujuan untuk menguji apakah penyimpangan yang muncul dalam pengukuran terhadap sampel masih ada dalam batas-batas kewajaran variabel yang diuji normalitas datanya. Pengujiannya menggunakan uji Kolmogorov-Smirnov dengan bantuan program SPSS 17.0 for windows dengan kriteria pengujian adalah jika probabilitas (Sig) > 0,05 maka data berdistribusi normal dan jika probabilitas (Sig) $<0,05$ maka distribusi data tidak normal. Uji homogenitas dimaksudkan untuk melihat apakah setiap kelompok yang akan dibandingkan mempunyai variasi yang selalu sama atau hampir sama, atau varian kesalahan adalah sama untuk level X. Jika varians kesalahan berbeda untuk nilai $X$ yang berbeda maka dalam distribusi itu menunjukkan adanya heterogenitas. Uji homogenitas dilakukan dengan bantuan SPSS 17.0 for windows. Kehomogenan data dilihat dari statistik yang didasarkan pada nilai probabilitas Levene' Test. Kriterianya adalah dengan taraf signifikansi uji $\partial=0,05$, jika signifikasi yang diperoleh (sig.F) > 0,05, maka variansi setiap data adalah sama atau homogen. Homogenitas matrik varian/covarian dapat dilihat dari hasil uji Box's Test of Equality of Covariance Matrices. Jika harga Box's M signifikan maka hipotesis nol yang menyatakan bahwa matrik varian/covarian dari variabel terikat sama ditolak. Dalam kondisi ini analisis MANCOVA tidak dapat dilanjutkan. MANCOVA dapat dilanjutkan apabila harga Box's $M$ yang diperoleh tidak signifikan, dengan demikian hipotesis nol diterima. Berarti matriks varian/covarian dari variabel terikat sama. Kriteria pengujian adalah data memiliki varians yang sama (homogen) jika angka signifikan yang dihasilkan lebih besar dari taraf signifikansi 0,05. Uji liniearitas berfungsi untuk mencari bentuk hubungan antara variabel bebas dengan variabel terikat. Teknik analisa yang digunakan adalah teknik analisa uji statistik $\mathrm{F}$ dengan bantuan SPSS 17.0 for Windows dengan taraf signifikansi $5 \%$. Linearitas dilihat dari nilai F-Deviation from Linearity, dengan kriteria jika F-Deviation from Linearity mempunyai nilai sig. > 0,05 maka data berkorelasi linear. Sebaliknya jika $F$ Deviation from Linearity mempunyai nilai sig. < 0,05 maka data yang dianalisis berkorelasi non-linear. Uji multikolinearitas dimaksudkan untuk mengetahui apakah terdapat hubungan yang cukup tinggi atau tidak antara motivasi belajar dengan pretasi belajar matematika siswa (variabel terikat). Jika tidak terdapat hubungan yang cukup tinggi, berarti tidak ada aspek yang sama diukur pada variabel tersebut, dengan demikian analisis bisa dilanjutkan. Pengujian ini dilakukan dengan bantuan SPSS 17,0 for Windows. Uji multikolinearitas dapat juga digunakan dengan menghitung koefisien varians inflation factor (VIP). Kriteria yang digunakan adalah, jika nilai VIP di sekitar angka 1 atau memiliki tolerance mendekati 1, maka dikatakan tidak terdapat masalah multikolinearitas.

Pengujian hipotesis pada penelitian ini menggunakan teknik MANCOVA (multivariat analysis of covarians). Dalam menganalisis data peneliti menggunakan program analisis data SPSS 17.0 for Windows dengan taraf signifikan 5\%.

\section{HASIL PENELITIAN DAN PEMBAHASAN}

Data yang diperoleh pada penelitian ini yaitu: (1) data motivasi belajar matematika pada siswa yang dibelajarkan model pembelajaran kooperatif tipe STAD, 
(2) data motivasi belajar matematika pada siswa yang dibelajarkan model pembelajaran kooperatif tipe STAD dengan media Geogebra, (3) data motivasi belajar matematika pada siswa yang dibelajarkan model pembelajaran konvensional, (4) data prestasi belajar matematika pada siswa yang dibelajarkan model pembelajaran kooperatif tipe STAD, (5) data prestasi belajar matematika pada siswa yang dibelajarkan model pembelajaran kooperatif tipe STAD dengan media Geogebra, dan (6) data prestasi belajar matematika pada siswa yang dibelajarkan model pembelajaran konvensional.

Analisis deskriptif terhadap data motivasi dan prestasi belajar matematika meliputi: rata-rata, median, modus, skor maksimum, skor minimum, jangkauan, simpangan baku, dan varians. Hasil analisis disajikan pada Tabel 1 dan Tabel 2 berikut.

Tabel 1. Rangkuman Hasil Statistik Deskriptif Data Motivasi Belajar

\begin{tabular}{ccccccc}
\hline & \multicolumn{7}{c}{ Model Pembelajaran } \\
\cline { 2 - 7 } Statistik & \multicolumn{2}{c}{ STAD + Geogebra } & \multicolumn{2}{c}{ STAD } & \multicolumn{2}{c}{ Konvensional } \\
\cline { 2 - 7 } & Pretes & Post tes & Pretes & Post tes & Pretes & Post tes \\
\hline $\mathrm{N}$ & 34 & 34 & 34 & 34 & 34 & 34 \\
\hline Mean & 118.09 & 137.35 & 115.35 & 130.62 & 110.41 & 122.32 \\
\hline Median & 119 & 136.5 & 114.5 & 127.5 & 110 & 121 \\
\hline Modus & 122 & 144 & 112 & 127 & 95 & 118 \\
\hline Minimum & 95 & 112 & 93 & 105 & 93 & 105 \\
\hline Maksimum & 142 & 163 & 143 & 149 & 131 & 143 \\
\hline Rentang & 47 & 51 & 50 & 44 & 38 & 38 \\
\hline Std Deviasi & 11.12 & 12.5 & 11.80 & 11.94 & 11.16 & 9.46 \\
\hline Varians & 123.66 & 156.17 & 139.33 & 142.49 & 124.61 & 89.5 \\
\hline
\end{tabular}

Tabel 2. Rangkuman Hasil Statistik Deskriptif Data Prestasi Belajar Matematika

\begin{tabular}{ccccccc}
\hline \multirow{2}{*}{ Statistik } & \multicolumn{7}{c}{ Model Pembelajaran } \\
\cline { 2 - 7 } & \multicolumn{1}{c}{ STAD + Geogebra } & \multicolumn{2}{c}{ STAD } & \multicolumn{2}{c}{ Konvensional } \\
\cline { 2 - 7 } & Pretes & Post tes & Pretes & Post tes & Pretes & Post tes \\
\hline $\mathrm{N}$ & 34 & 34 & 34 & 34 & 34 & 34 \\
\hline Mean & 8.53 & 20.21 & 7.15 & 16.15 & 6.77 & 11.50 \\
\hline Median & 9 & 20 & 7 & 16.5 & 6.5 & 11 \\
\hline Modus & 10 & 19 & 7 & 17 & 6 & 10 \\
\hline Minimum & 5 & 12 & 3 & 8 & 4 & 6 \\
\hline Maksimum & 13 & 29 & 12 & 22 & 11 & 18 \\
\hline Rentang & 8 & 17 & 9 & 14 & 7 & 12 \\
\hline Std Deviasi & 2.23 & 2.92 & 2.15 & 2.85 & 1.99 & 2.79 \\
\hline Varians & 4.98 & 8.53 & 4.61 & 8.13 & 3.94 & 7.77 \\
\hline
\end{tabular}

Berdasarkan Tabel di atas, setelah diberikan perlakuan diperoleh bahwa skor rata-rata motivasi belajar matematika pada kelompok siswa yang belajar dengan model pembelajaran kooperatif tipe STAD dengan media Geogebra lebih tinggi daripada skor rata-rata motivasi belajar matematika pada kelompok siswa yang belajar dengan model pembelajaran kooperatif tipe STAD. Skor rata-rata motivasi belajar matematika pada kelompok siswa yang belajar dengan model pembelajaran STAD lebih tinggi jika dibandingkan dengan skor rata-rata motivasi belajar matematika pada kelompok siswa yang belajar dengan model pembelajaran konvensional. Hasil ini menunjukkan bahwa tampaknya model pembelajaran kooperatif tipe STAD dengan media Geogebra memberi pengaruh yang positif terhadap motivasi belajar matematika. Skor rata-rata prestasi belajar 
matematika pada kelompok siswa yang belajar dengan model pembelajaran STAD dengan media Geogebra lebih tinggi dibandingkan dengan skor rata-rata prestasi belajar matematika pada kelompok siswa yang belajar dengan model pembelajaran STAD. Skor rata-rata prestasi belajar matematika pada kelompok siswa yang belajar dengan model pembelajaran STAD lebih tinggi jika dibandingkan dengan skor rata-rata prestasi belajar matematika pada kelompok siswa yang belajar dengan model pembelajaran konvensional. Hasil ini memperlihatkan bahwa tampaknya model pembelajaran kooperatif tipe STAD dengan media Geogebra memberi pengaruh yang positif terhadap motivasi belajar matematika.

Hasil uji hipotesis pertama dengan SPSS 17,0 for windows diperoleh bahwa nilai signifikansi untuk Pillai's Trace, Wilks' Lambda, Hotelling's Trace, dan Roy's Largest Root pada model pembelajaran memiliki nilai signifikansi sebesar 0,000. Nilai signifikansi ini lebih kecil dari taraf signifikansi yang ditetapkan sebesar 0,05 sehingga nilai sig $\mathrm{F}$ untuk Pillai's Trace, Wilks' Lambda, Hotelling's Trace, dan Roy's Largest Root semuanya signifikan. Ini berarti bahwa hipotesis nol $\left(\mathrm{H}_{0}\right)$ yang diajukan "ditolak" dan hipotesis alternatif $\left(\mathrm{H}_{1}\right)$ "diterima". Jadi dapat disimpulkan bahwa terdapat perbedaan motivasi dan prestasi belajar matematika antara siswa yang belajar dengan model pembelajaran kooperatif tipe STAD dengan media GeoGebra, model pembelajaran kooperatif tipe STAD, dan model pembelajaran konvensional. Perbedaan motivasi dan prestasi belajar pada masing-masing kelompok disebabkan model pembelajaran yang diterapkan.

Pada model pembelajaran konvensional yang berpusat pada guru, siswa terbiasa menerima secara pasif informasi yang diberikan guru. Siswa tidak tahu dan merasa tidak perlu berusaha menemukan konsep-konsep terkait materi yang dipelajari. Pembelajaran konvensional yang bersifat individualistik dan kompetitif menyebabkan siswa yang berkemampuan akademik rendah akan merasa semakin tertinggal sehingga kurang termotivasi dalam belajar.

Pada model pembelajaran kooperatif tipe STAD siswa belajar dan bekerja sama dalam kelompoknya untuk mengerjakan tugas yang dibebankan. Setiap anggota kelompok mempunyai kewajiban membantu teman satu kelompoknya untuk memastikan bahwa semua anggota kelompok memahami materi pelajaran yang diberikan. Dengan adanya bantuan dari siswa yang sudah paham materi, maka siswa yang kemampuan rendah akan termotivasi untuk menguasai materi yang sedang dibahas. Dan karena dalam pembelajaran kooperatif terdapat unsur penghargaan, maka semua siswa akan termotivasi untuk memperoleh hasil maksimal dalam pembelajaran sehingga kelompoknya mendapat penghargaan terbaik.

Selanjut pada model pembelajaran kooperatif tipe STAD dengan media GeoGebra, materi disampaikan secara dinamis sehingga akan menarik minat siswa dalam belajar matematika. Media GeoGebra dapat mengurangi keabstrakan konsep-konsep matematika yang dipelajari, karena GeoGebra mampu memvisualisasikan konsep pada matematika yang bersifat abstrak. Dengan berkurangnya kesan abstrak konsep matematika dengan bantuan media GeoGebra, diharapkan siswa akan lebih tertarik dan termotivasi untuk mempelajari.

Hasil penelitian ini mempertegas hasil temuan Sumargi (2015) dalam penelitian yang berjudul "Pengaruh Pembelajaran Kooperatif tipe STAD terhadap Motivasi Belajar dan Prestasi Belajar IPA Siswa Kelas VI Negeri 3 Bedulu Tahun Pelajaran 2013/2014", memperoleh simpulan bahwa terdapat perbedaan yang signifikan antara motivasi belajar dan prestasi belajar IPA siswa yang mengikuti pembelajaran model pembelajaran kooperatif tipe STAD dengan siswa yang mengikuti pembelajaran konvensional, dimana motivasi dan pretasi belajar IPA pada siswa yang mengikuti pembelajaran model pembelajaran 
kooperatif tipe STAD lebih baik dibandingkan dengan siswa yang mengikuti pembelajaran konvensional. Hasil dan kajian teori pada penelitian ini, menunjukkan bahwa pembelajaran kooperatif tipe STAD secara empiris dapat meningkatkan motivasi belajar siswa dan juga prestasi belajar.

Terkait dengan penggunaan media Geogebra, Fitriyani (2014) dalam penelitian pengembangannya memperoleh hasil bahwa produk perangkat pembelajaran yang dikembangkan telah memenuhi kriteria sangat efektif ditinjau dari prestasi dan motivasi belajar siswa, sebanyak $83,33 \%$ siswa berhasil mencapai KKM yang ditetapkan dan $87,5 \%$ siswa memiliki motivasi belajar matematika yang tinggi.

Hasil uji hipotesis kedua menunjukkan bahwa pada model pembelajaran, untuk variabel motivasi nilai F sebesar 9,377 dengan nilai signifikansi 0,000 . Nilai signifikansi hasil perhitungan ini lebih kecil dari taraf signifikansi yang ditetapkan sebesar 0,05 sehingga hipotesis nol $\left(\mathrm{H}_{0}\right)$ yang diajukan "ditolak" dan hipotesis alternatif $\left(H_{1}\right)$ "diterima". Jadi, disimpulkan bahwa terdapat perbedaan motivasi belajar matematika antara siswa yang belajar dengan model pembelajaran kooperatif tipe STAD dengan media GeoGebra, model pembelajaran kooperatif tipe STAD, dan model pembelajaran konvensional.

Dengan membandingkan skor ratarata post tes motivasi belajar matematika pada tiap-tiap kelompok perlakuan diperoleh bahwa: 1) skor rata-rata motivasi belajar matematika terbesar diperoleh oleh kelompok siswa yang dibelajarkan dengan model pembelajaran kooperatif tipe STAD dengan media GeoGebra, dan skor ratarata motivasi belajar matematika kelompok siswa yang dibelajarkan dengan model pembelajaran kooperatif tipe STAD lebih besar jika dibandingkan dengan skor ratarata motivasi belajar matematika kelompok siswa yang dibelajarkan dengan model pembelajaran konvensional.

Pada analisis data uji beda mean juga diperoleh bahwa skor rata-rata motivasi belajar matematika pada kelompok siswa yang dibelajarkan dengan model pembelajaran kooperatif tipe STAD dengan media Geogebra, kelompok siswa yang dibelajarkan dengan model pembelajaran kooperatif tipe STAD, dan kelompok siswa yang dibelajarkan dengan model pembelajaran konvensional adalah berbeda secara signifikan.

Hasil ini menunjukkan bahwa model pembelajaran kooperatif tipe STAD dengan media Geogebra paling efektif dalam menumbuhkan motivasi belajar matematika siswa. Hal ini terjadi karena pada model kooperatif tipe STAD dengan media Geogebra siswa diberikan kesempatan untuk bekerja dalam kelompoknya dalam menyelesaikan tugastugas kelompok. Pemberian penghargaan atas kemajuan yang diperoleh pada masing-masing kelompok akan membuat setiap anggota kelompok termotivasi untuk mengerjakan tugas dengan hasil terbaik.

Pada model pembelajaran kooperatif tipe STAD, anggota kelompok yang dengan kemampuan akademik tinggi akan termotivasi membantu anggota kelompok dengan kemampuan akademik yang lebih rendah karena dalam model pembelajaran kooperatif tipe STAD skor individu dalam kelompok berpengaruh terhadap skor anggota yang lain dalam kelompoknya. Sedangkan penggunaan media Geogebra pada saat fase penyajian informasi (presentasi), yang mampu membuat animasi dan gerakan-gerakan manipulasi terkait dengan materi yang disajikan akan memberikan pengalaman visual menarik bagi siswa sehingga siswa lebih termotivasi untuk belajar.

Hasil penelitian ini mempertegas temuan-temuan empiris sebelumnya yang berkaitan dengan penerapan model pembelajaran kooperatif tipe STAD dan penggunaan media Geogebra dalam pembelajaran Matematika. Sumargi (2015) dalam penelitian yang berjudul "Pengaruh Pembelajaran Kooperatif tipe STAD terhadap Motivasi Belajar dan Prestasi Belajar IPA Siswa Kelas VI Negeri 3 Bedulu Tahun Pelajaran 2013/2014", memperoleh simpulan bahwa terdapat 
perbedaan yang signifikan antara motivasi belajar dan prestasi belajar IPA siswa yang mengikuti pembelajaran model pembelajaran kooperatif tipe STAD dengan siswa yang mengikuti pembelajaran konvensional. Nazihatulhasanah (2014) dalam penelitian yang berjudul "The Effects of GeoGebra on Students Achievement' yang merupakan penelitian eksperimen pada 62 orang sampel menemukan bahwa penggunaan software GeoGebra dalam proses pembelajaran dapat memberikan pengaruh yang kuat dalam meningkatkan kemampuan siswa pada penyelesaian masalah statistik. GeoGebra dapat memberikan pandangan yang baik pada siswa terhadap mata pelajaran matematika. Penggunaan software GeoGebra juga dapat meningkatkan minat siswa, kepercayaan diri dan motivasi siswa dalam belajar matematika.

Pada uji hipotesis ketiga diperoleh bahwa untuk variabel prestasi pada model pembelajaran, nilai $F$ sebesar 92,508 dengan nilai signifikansi 0,000 . Nilai signifikansi hasil perhitungan ini lebih kecil dari taraf signifikansi yang ditetapkan sebesar 0,05 sehingga hipotesis nol $\left(\mathrm{H}_{0}\right)$ yang diajukan "ditolak" dan hipotesis alternatif $\left(\mathrm{H}_{1}\right)$ "diterima". Dengan demikian disimpulkan bahwa terdapat perbedaan prestasi belajar matematika antara siswa yang belajar dengan model pembelajaran kooperatif tipe STAD dengan media GeoGebra, model pembelajaran kooperatif tipe STAD, dan model pembelajaran konvensional.

\section{PENUTUP}

Berdasarkan hasil analisis data dan pembahasan, dapat disimpulkan bahwa: 1) terdapat perbedaan motivasi dan prestasi belajar matematika secara bersama-sama antara siswa yang belajar dengan model pembelajaran kooperatif tipe STAD dengan media GeoGebra, model pembelajaran kooperatif tipe STAD, dan model pembelajaran konvensional; 2) terdapat perbedaan motivasi belajar matematika antara siswa yang belajar dengan model pembelajaran kooperatif tipe STAD dengan media
GeoGebra, model pembelajaran kooperatif tipe STAD, dan model pembelajaran konvensional; dan 3) terdapat perbedaan prestasi belajar matematika antara siswa yang belajar dengan model pembelajaran kooperatif tipe STAD dengan media GeoGebra, model pembelajaran kooperatif tipe STAD, dan model pembelajaran konvensional.

Beberapa saran untuk peningkatan kualitas pembelajaran matematika terkait dengan hasil penelitian ini yaitu: 1) model pembelajaran kooperatif tipe STAD dengan yang dibarengi dengan penggunaan media Geogebra dapat dijadikan alternatif model pembelajaran yang diterapkan oleh guruguru dalam menumbuhkan motivasi belajar matematika siswa. Hasil penelitian ini telah menunjukkan bahwa model pembelajaran kooperatif tipe STAD dengan media Geogebra dapat berpengaruh positif terhadap motivasi belajar matematika siswa jika dibandingkan dengan model pembelajaran STAD dan konvensional; 2) model pembelajaran kooperatif tipe STAD dengan disertai penggunaan media Geogebra dapat dijadikan alternatif model pembelajaran yang diterapkan oleh guruguru untuk meningkatkan prestasi belajar matematika siswa. Hal ini sesuai dengan hasil penelitian ini, yang menunjukkan bahwa model pembelajaran kooperatif tipe STAD dengan media Geogebra menghasilkan prestasi belajar matematika siswa tertinggi dibandingkan dengan model pembelajaran STAD dan konvensional.

Hasil post tes prestasi belajar matematika pada masing-masing kelompok perlakuan menunjukkan bahwa skor rata-rata prestasi belajar matematika tertinggi diperoleh oleh kelompok siswa yang dibelajarkan dengan model pembelajaran kooperatif tipe STAD dengan media GeoGebra. Skor rata-rata prestasi belajar matematika kelompok siswa yang dibelajarkan dengan model pembelajaran kooperatif tipe STAD lebih besar jika dibandingkan dengan skor rata-rata prestasi belajar matematika kelompok siswa yang dibelajarkan dengan model pembelajaran konvensional. 
Pada analisis data uji beda mean juga diperoleh bahwa skor rata-rata prestasi belajar matematika pada kelompok siswa yang dibelajarkan dengan model pembelajaran kooperatif tipe STAD dengan media Geogebra, kelompok siswa yang dibelajarkan dengan model pembelajaran kooperatif tipe STAD, dan kelompok siswa yang dibelajarkan dengan model pembelajaran konvensional adalah berbeda secara signifikan. Hasil ini menunjukkan bahwa model pembelajaran kooperatif tipe STAD dengan media Geogebra paling efektif dalam meningkatkan prestasi belajar matematika siswa.

Hasil penelitian ini sejalan dengan beberapa temuan empiris pada penelitian yang dilakukan oleh Puji Ayuni (2014) yang berjudul "Eksperimentasi Model Pembelajaran Kooperatif Tipe Teams Games Tournament dan Student Teams Achievement Division Berbantuan Media GeoGebra pada Materi Program Linear Ditinjau dari Kreativitas Belajar Siswa Kelas XII IPA SMA Negeri se-kabupaten Kudus Tahun Pelajaran 2013/2014", yang menyimpulkan bahwa terdapat perbedaan prestasi belajar antara model pembelajaran STAD berbantuan media GeoGebra dan model pembelajaran langsung. Dengan melihat rerata marginalnya maka prestasi belajar model pembelajaran STAD berbantuan media GeoGebra lebih baik daripada model pembelajaran langsung.

\section{DAFTAR RUJUKAN}

Djamarah, S. B. \& Zain, A. 2006. Stategi belajar mengajar. Jakarta: PT Asdi Mahasatya.

Eka Aryasuta, I W., Suparta, I N., \& Suweken, G. 2014. Pengaruh model pembelajaran berbasis masalah dengan media berbantuan GeoGebra terhadap prestasi belajar matematika siswa ditinjau dari tingkat ketangguhan siswa. eJournal Program Pascasarjana. Universitas Pendidikan Ganesha Program Studi Pendidikan Matematika, 3 (1). Tersedia pada http:// pasca.undiksha.ac.id/e-journal/ index.php/JPM/article/ view/1460. Diakses 15 Januari 2016.

Fitriyani, W. \& Sugiman. 2014. Pengembangan perangkat pembelajaran teorema pythagoras dengan pendekatan IDEAL berbantuan geogebra. Journal Riset Pendidikan Matematika. 1 (2). Tersedia pada http://journal.uny.ac. id/index.php/ irpm/article/viewFile/2681/2234. Diakses 29 Januari 2016.

Hamalik, O. 2008. Belajar mengajar. Jakarta: PT Bumi Aksara.

Hohenwarter, M., Hohenwarter, J., Kreis, Y. \& Lavicza, Z. 2008. Teaching and learning calculus with free dynamic mathematics software geogebra. Jurnal ICME. 11. Tersedia

http://archive.geogebra.org/ static/publications/ 2008-ICMETSG16-Calculus-GeoGebra-

Paper.pdf. Diakses 1 Januari 2016.

Kawiwati. 2009. Pengaruh model pembelajaran problem based learning berbasis asesmen portofolio terhadap hasil belajar matematika ditinjau dari keterampilan berpikir kritis pada siswa kelas $X$ SMA Negeri 1 Payangan. Tesis (tidak diterbitkan). Program Pascasarjana Undiksha Singaraja.

Mahmudi, A. 2010. Membelajarkan geometri dengan program geogebra. Makalah. Disajikan pada Seminar Nasional Matematika dan Pendidikan Matematika. Universitas Negeri Yogyakarta.

Nazihatulhasanah, A., \& Nurbiha A. S. 2014. The effects of geogebra on students achievement. Procedia Social and Behavioral Sciences. 172: 208-214.. Tersedia pada http://ac.elscdn.com/S1877042815003936/1s2.0-S1877042 815003936main.pdf??tid=104e8382-e8d5-11e5b119-0000aacb362\&acdnat=1457843930_06037df0bdaba 2701c8af4970ff47ce7. Diakses 17 Januari 2016. 
Puji Ayuni, Mardiyana, \& Riyadi. 2014. Eksperimentasi model pembelajaran kooperatif tipe teams games tournament dan student teams achievement division berbantuan media geogebra pada materi program linear ditinjau dari kreativitas belajar siswa kelas XII IPA SMA Negeri se-kabupaten Kudus tahun pelajaran 2013/2014. Jurnal Elektronik Pembelajaran $\begin{array}{lll}\text { Matematika. } 2 & \text { (3). 270-280 }\end{array}$ Tersedia pada http://jurnal.fkip.uns.ac.id/ index.php/s2math/article/view/3964. Diakses 17 Januari 2016

Preiner, J. 2008. Introducing Dynamic Mathematics Software to Mathematics Teachers: the Case of GeoGebra. Desertasi (tidak diterbitkan). Faculty of Natural Sciences University of Salzburg.

Suherman \& Winataputra. 1993. Strategi belajar mengajar matematika. Jakarta: Depdikbud.

Sumargi, S. A. K., Marhaeni, A. A. I. N., \& Widiartini, K. 2015. Pengaruh pembela-jaran kooperatif tipe STAD terhadap motivasi belajar dan prestasi belajar IPA siswa kelas VI Negeri 3 Bedulu tahun pelajaran 2013/2014. e-Journal Program Pascasarjana Universitas Pendidikan Ganesha Program Studi Penelitian dan Evaluasi Pendidikan. 5(1). Tersedia pada http://pasca. undiksha.ac.id/ejournal/index.php/jurnal_ep/article/v iew/1577/1233. Diakses 15 Januari 2016.
Suweken, G. 2011. Pengaruh interaktif antara struktur pembelajaran berbantuan applet dan tingkat kemampuan siswa terhadap hasil belajar matematika siswa SMP kelas VIII di kabupaten Buleleng. Laporan Hasil Penelitian (tidak diterbitkan). Universitas Pendidikan Ganesha Singaraja.

Suweken, G. 2011. Pengembangan mathlet matematika eksploratif untuk meningkatkan kompetensi matematika siswa SMP kelas VIII di Singaraja. Hasil Penelitian (tidak diterbitkan). Universitas Pendidikan Ganesha Singaraja.

Trianto. 2012. Mendesain model pembelajaran inovatif-progresif. Jakarta: Kencana Prenada Media Group.

Widyaningrum, Yulia Tri \& Murwaningtyas, C. E. 2012. Pengaruh media pembelajaran geogebra terhadap motivasi dan hasil belajar siswa pada materi grafik fungsi kuadrat di kelas X SMA Negeri 2 Yogyakarta tahun pelajaran 2012/2013. Makalah. Disampaikan dalam Seminar Nasional Matematika dan Pendidikan Matematika di Universitas Negeri Yogyakarta, 10 November 2012.

Wulandari, I G. A. P. A. 2011. Pengembangan perangkat pembelajaran matematika realistik berbantuan TIK dalam upaya meningkatkan aktivitas dan prestasi belajar matematika siswa kelas XI SMK. Tesis (tidak diterbitkan). Universitas Pendidikan Ganesha Singaraja.. 